\title{
PEMANFAATAN ENERGI ARUS LAUT PADA TELUK AWERANGE SEBAGAI SUMBER ENERGI ALTERNATIF YANG BEKERLANJUTAN
}

\author{
*Firman Husain dan Windi Widianingrum \\ Departemen Teknik Kelautan Universitas Hasanuddin \\ *firman.husaian@gmail.com
}

\begin{abstract}
Abstrak
Indonesia memiliki luas laut $96.079 \mathrm{~km} 2$ dan panjang garis pantai sebesar $99.093 \mathrm{~km}$, membuat Indonesia memiliki potensi untuk memanfaatkan laut sebagai sumber energi baru terbarukan. Namun pemanfaatan energi baru terbarukan saat ini baru mencapai 6,2\% pada tahun 2015. Salah satu energi laut yang dapat dimanfaatkan adalah arus laut. Teluk Awerange yang terletak di Sulawesi Selatan merupakan titik yang memiliki sumber energi laut dan dapat dimanfaatkan menjadi energi terbarukan berkelanjutan yang ramah lingkungan. Kecepatan arus di wilayah Teluk Awerange dalam kondisi surut dapat mencapai 0,25-0,36 m/s. Sehingga dapat memungkinkan untuk menggunakan energi pasang surut dengan menggunakan turbin. Turbin Kobold memanfaatkan arus dari air laut pada Teluk Awerange. Dengan menggunakan turbin bi-directional (dua arah) yang menggerakkan turbin searah jarum jam maupun sebaliknya. Turbin yang dipasang secara horizontal pada dasar laut dapat mengubah energi kinetik dari turbin menjadi energi listrik saat pasang surut, menjadikan turbin layak digunakan sebagai pembangkit energi listrik tenaga pasang surut laut. Sebagai sampel berdasarkan Kementrian ESDM energi arus dapat menghasilkan 1,2 MW/turbin. Keuntungan besar dari turbin bidirectional adalah bahwa bilah baling-baling tidak perlu dibalik ketika arah aliran berubah. Hal ini membuat desain yang kuat, lebih murah untuk membangun, dirawat dan resiko kerusakan lebih rendah. Juga turbin dua arah rata-rata menghasilkan dua kali energi listrik dari yang dihasilkan oleh turbin uni-directional, yang hanya berfungsi selama pasang surut atau banjir.
\end{abstract}

Kata Kunci: Energi Terbarukan, Pasang Surut, Turbin Kobold.

\begin{abstract}
Indonesia has a sea area of 96,079 $\mathrm{km} 2$ and a coastline of 99,093 km, making Indonesia has the potential to utilize the sea as a new and renewable energy source. However, the use of new and renewable energy has only reached $6.2 \%$ in 2015. One of the marine energies that can be utilized is ocean currents. Awerange Bay, located in South Sulawesi, is a point that has a source of marine energy and can be used as an environmentally friendly, sustainable renewable energy. The current velocity in the Awerange Bay area in low tide can reach $0.25-0.36 \mathrm{~m} / \mathrm{s}$. So it can be possible to use tidal energy using turbines. The Kobold turbines take advantage of currents from seawater in Awerange Bay. By using a bidirectional (two-way) turbine that moves the turbine clockwise or vice versa. Turbines that are installed horizontally on the seabed can convert the kinetic energy of the turbines into electrical energy during tides, making the turbines suitable for use as marine tidal power generation. As a sample based on the Ministry of Energy and Mineral Resources, current energy can produce 1.2 MW/ turbine. The big advantage of bi-directional turbines is that the propeller blades do not need to be reversed when the flow direction changes. This makes for a robust design, less expensive to build, maintain, and a lower risk of breakage. Also two-way turbines on average produce twice the electrical energy that uni-directional turbines, which only function during tides or floods.
\end{abstract}

Keyword: Renewable Energy, Tides, Kobold Turbines.

\section{PENDAhUlan}

Energi memiliki peran penting dan tidak dapat dilepaskan dalam kehidupan manusia. Terlebih, saat ini hampir copyright is published under Lisensi Creative Commons Atribusi 4.0 Internasional. 
semua aktivitas manusia sangat tergantung pada energi. Terdapat dua kelompok besar energi yang didasarkan pada pembaharuan. Dua kelompok tersebut adalah energi terbarukan dan energi yang tersedia terbatas di alam (energi fosil). Pemanfaatan energi yang tidak dapat diperbaharui secara berlebihan dapat menimbulkan krisis energi, pada saat ini kita dihadapkan pada situasi menipisnya cadangan sumber energi fosil dan meningkatnya kerusakan [1] lingkungan akibat penggunaan energi fosil. Berdasarkan data kementrian ESDM RI, konsumsi energi di Indonesia yang cukup tinggi hampir 95\% dari bahan bakar fosil. Dari total tersebut, hampir 50\% nya merupakan bahan bakar minyak (BBM). Di lain sisi terdapat potensi sumber energi terbarukan yang masih belum dimanfaatkan secara optimal, apalagi di negara kita ini masih bergantung kepada sumber energi fosil yang ketersediaannya terbatas di alam [2].

Melihat kondisi tersebut maka saat ini sangat diperlukan pengetahuan tentang apa itu energi terbarukan, sumber-sumber energi tebarukan, sekaligus masalah yang timbul dari pemanfaatan energi terbarukan agar didapatkan solusi atau kebijakan tentang pemanfaatan energi tersebut [3]. Secara sederhana, energi terbarukan didefinisikan sebagai energi yang dapat diperoleh ulang (terbarukan). Sumber energi terbarukan adalah sumber energi ramah lingkungan yang tidak mencemari lingkungan dan tidak memberikan kontribusi terhadap perubahan iklim dan pemanasan global. Energi fosil memiliki tradisi penggunaan yang panjang, sementara energi tebarukan masih sulit bersaing dengan energi fosil. Energi terbarukan masih perlu meningkatkan daya saing, karena sumber energi yang terbarukan masih membutuhkan subsidi untuk tetap kompetitif dengan energi fosil dalam hal biaya, serta energi terbarukan juga masih perlu mengingkatkan efisiensinya. Maka dari itu, hal yang paling penting untuk dilakukan sekarang adalah mengembangkan teknologi yang berbeda bagi energi terbarukan guna memastikan bahwa saat datangnya hari dimana energi fosil habis, dunia tidak perlu khawatir dan energi tebarukan sudah siap untuk menggantikannya [4].

Berdasarkan laporan PT. PLN, permintaan listrik terus meningkat dari tahun ke tahun seiring dengan melonjaknya jumlah penduduk dan berkembangnya kegiatan sektor ekonomi di wilayah Kabupaten Barru dan Pangkep. Beberapa kegiatan industri yang berkembang di daerah ini adalah industri pengolahan hasil pertanian, perkebunan, perikanan dan industri pengolahan makanan yang bahan bakunya dari alam. Kondisi ini sangat menyulitkan PLN terutama pada daerah daerah yang sulit dijangkau oleh listrik [5]. seperti daerah pesisir dan pulau-pulau kecil yang bertebaran di kedua wilayah tersebut. Oleh karena itu, diperlukan suatu terobosan untuk dapat memenuhi kebutuhan listrik pada daerah pesisir dan pulau-pulau kecil yang mulai berkembang kondisi perekonomiannya. Salah satu solusi yang mungkin dapat membantu penyediaan listrik di kedua daerah tersebut diantaranya adalah dengan pengembangan energi laut (arus laut) untuk tenaga listrik. Untuk dapat menggunakan energi laut sebagai pembangkit listrik diperlukan suatu penelitian atau pemetaan potensi energi laut yang lengkap dan bertahap. Penelitian dimulai dari inventarisasi potensi sumber daya energi laut, perhitungan potensi daya listrik yang dihasilkan dan studi kelayakan lokasi pembangkit listriknya. Tahap awal yang paling penting adalah mengetahui potensi energi kelautan yang ada saat ini, yaitu dengan cara melakukan penelitian dan pemetaan zonasi potensi energi alternatif kelautan pada lokasi-lokasi yang diperkirakan potensial. Dilihat dari posisi geografis dan sistem perairan regional daerah Kabupaten Barru dan Pangkep termasuk kedalam sistem perairan Selat Makassar. Perairan Selat Makassar adalah merupakan salah satu perairan di wilayah Indonesia bagian tengah

\subsection{Energi Arus Laut}

Arus laut adalah pergerakan massa air di laut baik itu secara vertikal atau secara horizontal sehingga membentuk gerakan seimbang yang sangat luas di seluruh lautan di dunia. Ada beberapa penyebab dari muncul nya air laut, diantaranya adalah tiupan angin atau perbedaan densitas atau pergerakan dari gelombang laut.

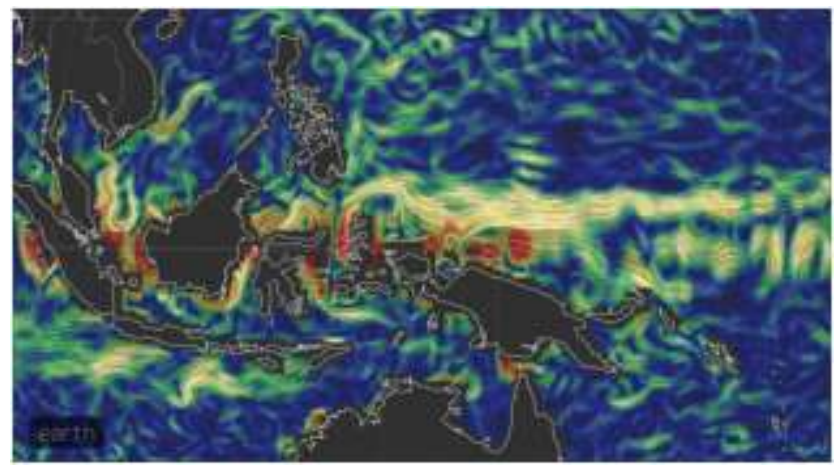

Gambar 1. Potensi Arus Laut Indonesia [5]

copyright is published under Lisensi Creative Commons Atribusi 4.0 Internasional. 
Energi arus atau gelombang laut merupakan salah satu bentuk energi yang dapat dimanfaatkan sebagai sumber energi penghasil listrik untuk mengatasi krisis energi yang terjadi di dunia saat ini. Pembangkit Listrik Tenaga Arus Laut merupakan jawaban atas kebutuhan energi listrik yang berasal dari sumber daya alam terbarukan, murah dan relatif mudah untuk diaplikasikan [5].

Pembangkit Listrik Tenaga Arus Laut mempunyai tiga komponen utama yang terdapat di dalamnya. Ketiga komponen tersebut adalah generator, turbin sebagai prime mover dan battery sebagai penyimpan energi yang telah dihasilkan. Pembangkit ini tidak dapat beroperasi secara penuh dalam 24 jam, hanya beroperasi berdasarkan periode debit arus laut yang paling efektif untuk memutar turbin. Oleh karena itu, diperlukan suatu sistem penyimpanan energi untuk menjamin kontinuitas pasokan energi listrik ke konsumen, meskipun pada saat generator sedang tidak beroperasi.

Diperlukan suatu sistem penyimpanan energi untuk menjamin kontinuitas pasokan energi listrik ke konsumen, meskipun pada saat generator sedang tidak beroperasi. Sistem penyimpanan energi tersebut berupa battery DC (accu) yang memiliki spesifikasi, karakteristik charge dan discharge khusus.

Listrik tenaga arus laut adalah salah satu teknologi yang sedang berkembang saat ini, yang memanfaatkan energi potensial kinetik dan gravitasi pada aliran pasang surut. Jika dibandingkan dengan sumber-sumber energi terbarukan lainnya, aliran arus laut merupakan sumber energi yang relatif dapat diandalkan, pergerakan arus dapat diprediksi secara akurat dalam arah, waktu dan besarnya. Jika dibandingkan dengan energi angin dan surya, energi ini memiliki sejumlah keunggulan antara lain: energi listrik yang dihasilkan bisa dimanfaatkan secara gratis, tidak membutuhkan bahan bakar, tidak menimbulkan efek rumah kaca, produksi listrik stabil karena pasang surut air laut bisa diprediksi, lebih hemat ruang dan tidak membutuhkan teknologi konversi yang rumit. Kelemahan energi ini diantaranya adalah membutuhkan alat konversi yang handal yang mampu bertahan dengan kondisi lingkungan laut yang keras yang disebabkan antara lain oleh tingginya tingkat korosi dan kuatnya arus laut.

\subsection{Turbin Kabold}

Turbin yang digunakan adalah turbin arus bawah laut Kobold yang merupakan hasil dari kerjasama antara Indonesia dengan tim mekanik dan elektrik dari Pda Archamedae Italy. Teknologi Kobold mengadopsi konsep propeler (baling-baling kapal) yang diputar arus vertikal, dapat menghasilkan daya sebesar 110 kilowatt (kW).

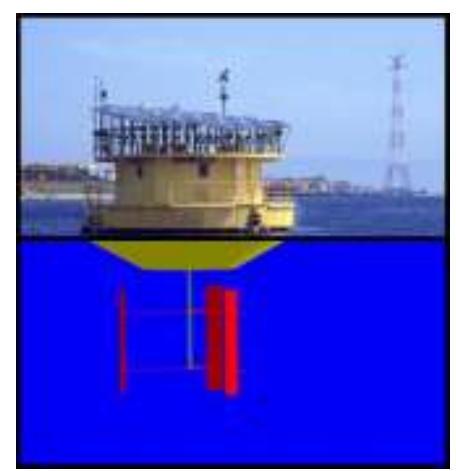

Gambar 2. Turbin Kobold

Turbin komposit dapat ditempatkan baik di pantai maupun di lepas pantai. Penempatan di darat misalnya di sepanjang garis pantai, melekat pada jembatan dan di sungai yang mengalir cepat. Keuntungan dari penempatan di laut adalah penghematan pada kabel listrik yang mahal, turbin tidak berada di rute kapal dan dapat dengan mudah diakses untuk pemeliharaan. Meskipun mereka ditempatkan di dekat pantai mereka tidak ada polusi horizon karena mereka benar-benar tenggelam.

Desain terbaru menunjukkan bahwa turbin masa depan untuk tujuan lepas pantai akan mendapatkan perumahan beton, yang akan memiliki banyak keuntungan: karena massa mereka sendiri tidak perlu pondasi yang mahal di dasar laut dan ada penghematan besar pada baja dan material komposit.

\subsection{Generator Asinkron}

Generator Asinkron (generator tak-serempak) sering digunakan untuk sistem turbin angin dan sistem mikrohidro yang putaran nya berubah-ubah sesuai dengan kecepatan angin dan debit air. Generator Asinkron yang digunakan pada sistem PLTAL Kobold ini adalah salah satu komponen terpenting dalam keseluruhan copyright is published under Lisensi Creative Commons Atribusi 4.0 Internasional. 
sistem PLTAL. Generator ini dapat mengubah energi gerak menjadi energi listrik. Prinsip kerja generator adalah berdasarkan induksi elektromagnetik. Tegangan dan arus listrik yang dihasilkan ini disalurkan melalui kabel jaringan listrik untuk akhirnya digunakan oleh masyarakat. Tegangan dan arus listrik yang dihasilkan oleh generator ini berupa AC (alternating current) yang memiliki bentuk gelombang kurang lebih sinusoidal [6].

\subsection{Rectifier}

Rectifier adalah alat yang digunakan untuk mengubah sumber arus bolak-balik (AC) menjadi sinyal sumber arus searah (DC). Rectifier yang digunakan adalah rectifier 3 phasa. Gelombang AC yang berbentuk gelombang sinus hanya dapat dilihat dengan alatukur CRO. Rangkaian rectifier banyak menggunakan transformator step down yang digunakan untuk menurunkan tegangan sesuai dengan perbandingan transformasi transformator yang digunakan. Daya rectifier tiga fasa yang akan digunakan harus sesuai dengan daya output dari pembangkit yaitu minimal sebesar $70 \mathrm{~kW}$, dengan efisiensi kerja $90 \%$.

\subsection{Sistem Penyimpanan Energi}

Karena keterbatasan ketersediaan akan energi arus laut (tidak sepanjang hari arus laut akan selalu tersedia) maka ketersediaan listrik pun tidak menentu. Oleh karena itu digunakan alat penyimpan energi berupa baterai (accu).

\subsection{Kapasitas Baterai}

Kapasitas baterai adalah jumlah ampere jam $(\mathrm{Ah}=$ kuat arus/Ampere $\mathrm{x}$ waktu/hour), artinya baterai dapat memberikan/menyuplai sejumlah isinya secara rata-rata sebelum tiap selnya menyentuh tegangan/voltase turun (drop voltage) yaitu sebesar 1,75 V (ingat, tiap sel memiliki tegangan sebesar $2 \mathrm{~V}$; jika dipakai maka tegangan akan terus turun dan kapasitas efektif dikatakan sudah terpakai semuanya bila tegangan sel telah menyentuh 1,75 V). Misal, baterai $12 \mathrm{~V} 75 \mathrm{Ah}$. Baterai ini bisa memberikan kuat arus sebesar 75 Ampere dalam satu jam artinya memberikan daya rata-rata sebesar 900 Watt (Watt $=\mathrm{V} \mathrm{x} \mathrm{I}=$ Voltase $\mathrm{x}$ Ampere $=12 \mathrm{~V}$ x 75 A). Secara hitungan kasar dapat menyuplai alat berdaya 900 Watt selama satu jam atau alat berdaya 90 Watt selama 10 jam, walaupun pada kenyataannya tidak seperti itu.

\subsection{Waktu dan Pengeluaran Arus Baterai}

Pengeluaran Lambat (berupa pengeluaran arus yang rendah) mengakibatkan waktu pengeluaran juga diperpanjang alias kapasitas lebih tinggi. Kapasitas yang dinyatakan untuk baterai yang umum pemakaiannya pada pengeluaran tertentu, biasanya $20 \mathrm{jam}$. Contoh nya adalah sebuah baterai $12 \mathrm{~V} 75 \mathrm{Ah}$ bisa dipakai selama 20 jam jika kuat arus rata-rata yang digunakan dalam 1 jam adalah 3,75 Ampere (75 Ah / $20 \mathrm{~h}$ ), sedangkan bila digunakan sebesar 5 Ampere maka waktu pemakaian bukannya 15 jam (75 Ah / $5 \mathrm{~A})$ tapi lebih kecil yaitu 14 jam, sedangkan pada penggunaan Ampere yang jauh lebih besar, yaitu 7,5 Ampere maka waktu pemakaian bukan 10 jam (75 A / 7,5 A) tapi hanya 7 jam. Hal ini bisa menjadi jawaban bagi mereka yang menggunakan UPS, misal 500 VA atau $500 \mathrm{Wh}$, yang mana baterai UPS hanya bertahan lebih kurang 5 - 15 menit untuk komputer yang memerlukan daya 250 Watt, padahal kalau berdasarkan hitungan kasar seharusnya bisa bertahan selama 2 jam (500 Watt.hour / 250 Watt).

\subsection{Pengukuran Kapasitas Baterai (Baterai Sizing)}

Untuk menjamin kontinuitas pasokan listrik, diperlukan baterai (accu) dengan kapasitas dan spesifikasi tetentu. Pengukuran kapasitas baterai yang akan digunakan adalah langkah terpenting, disamping penentuan bagaimana baterai tersebut dirangkai (jenis rangkaian yang digunakan, apaka seri, pararel atau seri- pararel). Berikut ini adalah daftar definisi dari parameter-parameter yaitu satuan dan istilah yang jamak ditemui dalam proses pengukuran kapasitas baterai:

a) Ampere (A) : Adalah satuan dari besarnya arus listrik yang harus dipasok oleh baterai menuju beban.

b) Volt (V): Adalah satuan dari tegangan, yaitu nilai perbedaan potensial dimana arus akan mengalir.

c) Watt (W): Adalah besaran dari daya listrik yang diperoleh dengan cara mengalikan nilai Tegangan (Volt) dengan nilai Arus (Ampere). 
d) Amperhour (Ah): Adalah satuan dari besarnya arus (Ampere) yang dapat dipasok oleh baterai dalam waktu tertentu (Hour). Nilai Ah dari suatu baterai didapat dengan cara mengalikan nilai arus yang dapat dipasok dengan suatu besaran waktu. Satuan besaran waktu juga menunjukkan waktu atau durasi discharge dari baterai tersebut. Contoh: Jika suatu baterai dapat memasok arus sebesar 10 A dalam waktu 5 jam, maka kapasitas Ah dari baterai tersebut adalah sebesar $50 \mathrm{Ah}$.

e) Watthour (Wh): Adalah satuan dari besarnya energi listrik yang dikonsumsi oleh beban. Nilai Wh dari suatu peralatan listrik didapat dengan cara mengalikan nilai besarnya daya listrik yang dikonsumsi dengan suatu besaran waktu. Contoh: Jika suatu beban mengkonsumsi daya listrik sebear 100 Watt dalam waktu 4 jam,maka besarnya KWh dari peralatan listrik tersebut adalah sebesar $400 \mathrm{KWh}$.

f) Baterai dirangkai secara seri: Ketika beberapa baterai dirangkai secara seri, maka nilai tegangan total dari rangkaian baterai tersebut didapat dengan menjumlahkan tiap nilai tegangan dari masing-masing baterai. Nilai Ah dari rangkaian baterai yang dirangkai secara seri adalah tetap (sama dengan nilai Ah dari masingmasing baterai penyusun rangkaian). Cara merangkai nya adalah dengan menghubungkan terminal positif dari suatu baterai dengan terminal negatif baterai lain nya.

g) Baterai dirangkai secara pararel: Ketika beberapa baterai dirangkai secara pararel, maka nilai tegangan total rangkaian baterai tersebut adalah tetap (sama dengan nilai tegangan dari masing-masing baterai penyusun rangkaian). Nilai AH dari rangkaian baterai yang dirangkai secara pararel akan meningkat, yang didapat dengan menjumlahkan tiap nilai Ah dari masing-masing baterai. Cara merangkainya adalah dengan cara menghubungkan terminal positif dari suatu baterai dengan terminal positf baterai lain nya.

h) Baterai dirangkai secara seri-pararel: Merupakan kombinasi dari rangkaian seri dan pararel. Pada jenis rangkaian ini, akan terjadi kenaikan nilai tegangan dan nilai Ah sesuai dengan jumlah baterai yang terdapat pada rangkaian. Dalam melakukan pengukuran kapasitas baterai, terdapat beberapa langkahlangkah, yaitu:

1. Menghitung nilai total KWH dari beban yang akan dipasok oleh baterai tersebut.

2. Menentukan seberapa lama baterai akan digunakan untuk memasik beban (waktu charge dan discharge). Sebaiknya baterai tidak mengalami discharge melebihi 50\% dari kapasitas total nya. Kapasitas AH yang tertulis pada suatu baterai, biasanya merupakan kapasitas baterai dengan waktu discharge selama 20 jam, ini berarti pada baterai berkapasitas $100 \mathrm{AH}$, akan memasok arus sebesar 5 Aselama $20 \mathrm{jam}$.

3. Menentukan besarnya kapasitas Ah maksimum yang dapat digunakan berdasarkan waktu discharge nya.

4. Menentukan jumlah unit baterai yang akan digunakan.

\subsection{Inverter}

Inverter digunakan untuk mengubah tegangan input DC menjadi tegangan AC. Keluaran inverter dapat berupa tegangan yang dapat diatur dan tegangan yang tetap. Sumber tegangan input inverter dapat menggunakan battery, cell bahan bakar, tenaga surya, atau sumber tegangan DC yang lain.

Daya inverter tiga fasa yang akan digunakan harus sesuai dengan besarnya daya maksimum dari beban yaitu minimal sebesar $28.775 \mathrm{~kW}$, oleh karena itu dipilih inverter yang berdaya $30 \mathrm{~kW}$ untuk menjaga kemungkinan terjadinya overload. Inverter yang digunakan memiliki efisiensi kerja sebesr $90 \%$

\subsection{Dasar Konversi dan Teori Arus Laut}

Arus laut merupakan gerakan horizontal massa air laut, sehingga arus laut memiliki energi kinetik yang dapat digunakan sebagai penggerak bagi sebuah rotor pembangkit listrik. Secara global, laut mempunyai sumber energi arus laut yang sangat besar yaitu sebesar 2,8 x 1014 (280 triliun) Watt-jam (Duxbury dkk., 2000). Selain itu arus laut ini menarik untuk dikembangkan sebagai pembangkit listrik karena sifatnya yang relatif stabil dan dapat diprediksi.

Pengembangan teknologi ekstraksi energi arus laut ini dilakukan dengan mengadaptasi prinsip teknologi ekstraksi energi dari angin yang telah lebih dulu berkembang yaitu dengan mengubah energi kinetik dari arus laut menjadi energi rotasi dan energi listrik. Kapasitas daya yang dihasilkan dihitung dengan pendekatan matematis yang memformulasikan daya yang dihasilkan dari suatu aliran fluida yang menembus suatu permukaan A dalam arah yang tegak lurus permukaan, dirumuskan sebagai berikut (Fraenkel, 1999, 2002):

$$
P=\frac{1}{2} \rho A\left|V^{3}\right|
$$


Keterangan, $\mathrm{P}$ adalah daya listri yang dihasilkan (watt), $\rho$ adalah rapat massa air $\left(\mathrm{kg} / \mathrm{m}^{3}\right)$, A adalah luas penampang $\left(\mathrm{m}^{2}\right)$ dan $\mathrm{V}$ merupakan kecepatan $(\mathrm{m} / \mathrm{s})$.

Luas permukaan turbin yang dimaksud adalah luas penampang turbin $=$ tinggi turbin $\mathrm{x}$ diameter turbin, sehingga besarnya daya yang dihasilkan selain tergantung besarnya kecepatan arus juga akan sangat tergantung pada ukuran dan jenis turbin yang digunakan. Tidak semua potensi sumber daya yang terkandung dalam arus laut tersebut dapat dikonversi menjadi energi. Secara umum besarnya energi yang dapat diekstrak tergantung dari jenis dan karakteristik turbin itu sendiri seperti ukuran diameter turbin arus. Melalui perhitungan seperti di atas dan dengan pengaitan rumus dengan rumusan energi dan diterapkan pada 2 jenis konverter yang telah diuji coba di perairan Indonesia, yaitu Kobold dan Marine Current maka dapat diperkirakan potensi daya yang terbangkit pada suatu daerah. Turbin Kobold Estimasi daya listrik yang dihasilkan dari konversi energi arus laut dengan menggunakan turbin Kobold (Coiro dkk., 2005) ditunjukkan dengan persamaan sebagai berikut:

$$
\mathrm{P}=\frac{1}{2} \rho \mathrm{A}\left|\mathrm{V}^{3}\right| \mathrm{n}
$$

Dimana P, $\rho, \mathrm{V}, \mathrm{A}$ dan $\eta$ masing-masing Daya Listrik yang dihasilkan (kW), Berat Jenis Air laut (1.025), Kecepatan Arus (m/sec), Luas Permukaan Blade (m2) sebesar $40 \mathrm{~m}^{2}$ dan Efesiensi untuk Turbin Kobold (\%) sebesar $50 \%$.

Mengacu pada rumus hubungan arus dan energi listrik yang dihasilkan pada persamaan di atas dapat dibuat sebuah grafik hubungan antara kecepatan arus dan output energi listrik yang dihasilkan (Gambar 3).

\section{METODE}

Pengukuran arus pada penelitian ini dilakukan dengan menggunakan peralatan Acoustic Doppler Current Profiler (ADCP) Mobile dan perangkat lunak Winriver. Alat ini dapat mengukur arah dan kecepatan arus secara bergerak pada kolom air dengan berbagai kedalaman. Kedalaman kolom air ini terbagi menjadi beberapa lapisan kolom air. Pada pengukuran ini interval lapisan kolom air diset 2 meter dengan blanking area pada lapisan kolom air kesatu sebesar 2 meter dari sensor alat ADCP, sehingga data arus terekam mulai dari kedalaman $3 \mathrm{~m}$ sampai kedalaman tertentu dengan selang 2 meter.

Prinsip kerja alat ADCP menggunakan efek Doppler dengan pemancaran bunyi pada frekuensi tertentu dan menerimanya kembali setelah dipantulkan. Bunyi ini dipantulkan sebagai akibat adanya pemantul bunyi berupa partikel kecil atau plankton. Pengukuran arus mobile dilakukan pada kondisi air berbeda, yaitu pada kondisi air pasang dan kondisi air surut. Pemilihan kondisi air ini dimaksudkan untuk mendapatkan variasi/ perubahan kecepatan arus dari kecepatan arus saat pasang dan surut. Lintasan pengukuran arus mobile bisa berbentuk zigzag atau searah garis pantai.

\section{HASIL DAN PEMBAHASAN}

\subsection{Hasil Pengukuran Arus Laut}

Pada tahap ini pengukuran arus laut pada wilayah Teluk Awerange dilakukan di beberapa titik. Pada tulisan ini diasumsikan 3 titik arus laut. Data arus laut pada kondisi surut menjadi acuan pada tulisan ini.

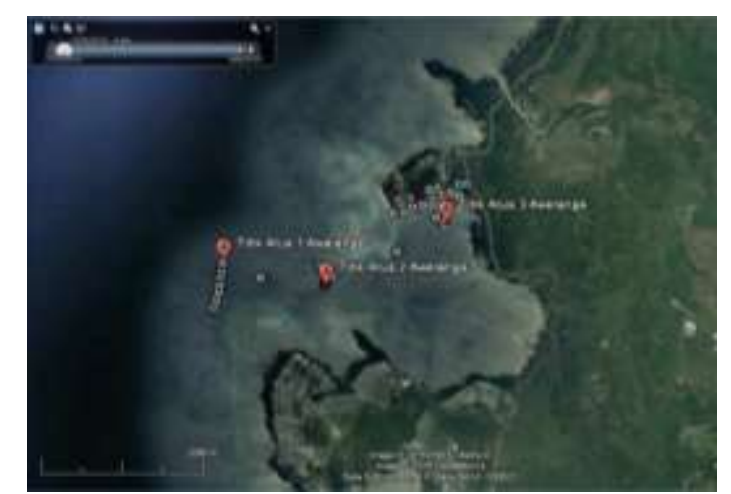

Gambar 4. dari Citra Satelit Teluk Awerange, Kab. Barru [5]

copyright is published under Lisensi Creative Commons Atribusi 4.0 Internasional. 
Di bawah ini disajikan tabel hasil pengukuran arus surut pada ketiga titik:

Tabel 1. Data Arus Surut Titik 1 dan 2 Teluk Awerange, Kab. Barru

Data Arus Surut Titik 1

\begin{tabular}{|c|c|c|c|c|c|c|c|c|c|}
\hline \multicolumn{2}{|c|}{ Koordinat } & \multirow[b]{2}{*}{$\begin{array}{l}\text { Perpind } \\
\text { ahan } \\
\text { (m) }\end{array}$} & \multirow[b]{2}{*}{$\begin{array}{l}\text { Waktu } \\
\text { (detik) }\end{array}$} & \multirow[b]{2}{*}{$\begin{array}{l}\text { Kecepat } \\
\text { an } \\
(\mathrm{m} / \mathrm{s})\end{array}$} & \multicolumn{2}{|c|}{ Koordinat } & \multirow[b]{2}{*}{$\begin{array}{l}\text { Perpind } \\
\text { ahan } \\
\text { (m) }\end{array}$} & \multirow{2}{*}{$\begin{array}{l}\text { Wakt } \\
\mathrm{u} \\
\text { (deti } \\
\mathrm{k} \text { ) }\end{array}$} & \multirow[b]{2}{*}{$\begin{array}{l}\text { Kecepata } \\
\mathrm{n} \\
(\mathrm{m} / \mathrm{s})\end{array}$} \\
\hline $\mathrm{x}(\mathrm{m})$ & $y(m)$ & & & & $\mathrm{x}(\mathrm{m})$ & $y(m)$ & & & \\
\hline 787413 & 9531935 & 37,3 & 60 & 0,62 & 788804 & 9532221 & 16 & 60 & 0,28 \\
\hline 787426 & 9531970 & 40,2 & 60 & 0,67 & 788808 & 9532237 & 14 & 60 & 0,23 \\
\hline 787439 & 9532008 & 41,5 & 60 & 0,69 & 788812 & 9532250 & 15 & 60 & 0,25 \\
\hline 787450 & 9532048 & 38,3 & 60 & 0,64 & 788812 & 9532265 & 14 & 60 & 0,23 \\
\hline 787463 & 9532084 & 32,2 & 60 & 0,54 & 788813 & 9532279 & 16 & 60 & 0,27 \\
\hline 787467 & 9532116 & 25,0 & 60 & 0,42 & 788812 & 9532295 & 16 & 60 & 0,27 \\
\hline 787467 & 9532115 & 40,0 & 60 & 0,67 & 788810 & 9532311 & 1 & 60 & 0,02 \\
\hline 787476 & 9532154 & 34,2 & 60 & 0,57 & 788810 & 9532310 & 15 & 60 & 0,26 \\
\hline 787480 & 9532188 & 39,1 & 60 & 0,65 & 788807 & 9532325 & 17 & 60 & 0,29 \\
\hline 787483 & 9532227 & 35,1 & 60 & 0,58 & 788801 & 9532341 & 21 & 60 & 0,36 \\
\hline 787485 & 9532262 & 36,2 & 60 & 0,60 & 788791 & 9532360 & 17 & 60 & 0,28 \\
\hline 787489 & 9532298 & 1,0 & 60 & 0,02 & 788783 & 9532375 & 17 & 60 & 0,29 \\
\hline 787489 & 9532297 & 34,9 & 60 & 0,58 & 788774 & 9532390 & 17 & 60 & 0,29 \\
\hline 787497 & 9532331 & 37,1 & 60 & 0,62 & 788765 & 9532405 & 13 & 60 & 0,22 \\
\hline 787506 & 9532367 & 32,8 & 60 & 0,55 & 788759 & 9532417 & & & \\
\hline 787513 & 9532399 & & & & & & & & \\
\hline \multicolumn{2}{|c|}{$\operatorname{Maximum}(\mathrm{m} / \mathrm{s})$} & & & 0,69 & \multicolumn{2}{|c|}{$\operatorname{Maximum}(\mathrm{m} / \mathrm{s})$} & & & 0,36 \\
\hline \multicolumn{2}{|c|}{$\operatorname{Minimum}(\mathrm{m} / \mathrm{s})$} & & & 0,02 & \multicolumn{2}{|c|}{$\operatorname{Minimum}(\mathrm{m} / \mathrm{s})$} & & & 0,02 \\
\hline \multicolumn{2}{|c|}{ Rerata $(\mathrm{m} / \mathrm{s})$} & & & 0,56 & \multicolumn{2}{|c|}{ Rerata $(\mathrm{m} / \mathrm{s})$} & & & 0,25 \\
\hline
\end{tabular}

Dari table 1 dapat terlihat bahwa data pengukuran kecepatan arus untuk lokasi 1 di Teluk Awerange Kabupaten Barru mencapai maximun dengan nilai $0.69 \mathrm{~m} / \mathrm{s}$ dan minimun dengan nilai $0,02 \mathrm{~m} / \mathrm{s}$ dan untuk table 2 dari data pengukuran kecepatan arus pada titik 2 didapatkan nilai maximum $0.36 \mathrm{~m} / \mathrm{s}$ dan minimum dengan nilai $0.02 \mathrm{~m} / \mathrm{s}$. dengan rerata masing-masing untuk titik 1 dan titik 2 adalah $0.56 \mathrm{~m} / \mathrm{s}$ dan $0.25 \mathrm{~m} / \mathrm{s}$.

Tabel 2. Data Arus Surut Titik 3 Teluk Awerange, Kab. Barru

\begin{tabular}{lllll}
\hline \multicolumn{6}{l}{ Data Arus Surut Titik 3} & \\
\cline { 1 - 4 } $\mathrm{K}(\mathrm{m})$ & $\mathrm{y}(\mathrm{m})$ & $\begin{array}{l}\text { Perpindahan } \\
(\mathrm{m})\end{array}$ & $\begin{array}{l}\text { Waktu } \\
(\text { detik })\end{array}$ & Kecepatan $(\mathrm{m} / \mathrm{s})$ \\
\hline 790313 & 9532941 & 10 & 60 & 0,17 \\
\hline 790311 & 9532951 & 10 & 60 & 0,17 \\
\hline 790309 & 9532961 & 11 & 60 & 0,19 \\
\hline 790306 & 9532972 & 12 & 60 & 0,20 \\
\hline 790301 & 9532983 & 13 & 60 & 0,22 \\
\hline 790291 & 9532992 & 12 & 60 & 0,20 \\
\hline 790282 & 9533000 & 14 & 60 & 0,24 \\
\hline 790271 & 9533009 & 1 & 60 & 0,02 \\
\hline 790271 & 9533008 & 11 & 60 & 0,19 \\
\hline 790262 & 9533015 & 13 & 60 & 0,21 \\
\hline 790252 & 9533023 & 12 & 60 & 0,20 \\
\hline 790242 & 9533030 & 12 & 60 & 0,20 \\
\hline Maximum $(\mathrm{m} / \mathrm{s})$ & & & 0,24 \\
\hline Minimum $(\mathrm{m} / \mathrm{s})$ & & & 0,02 \\
\hline Rerata $(\mathrm{m} / \mathrm{s})$ & & & 0,19 \\
\hline
\end{tabular}

Pada table 2 didapatkan kecepatan arus pada titik 3 dengan kecepatan arus maksimum adalah $0.24 \mathrm{~m} / \mathrm{s}$ dan copyright is published under Lisensi Creative Commons Atribusi 4.0 Internasional. 
kecepatan arus minimumnya diperoleh nilai $0.02 \mathrm{~m} / \mathrm{s}$ serta untuk rata-rata nilai kecepatan arus pada titik tersebut adalah 0.19 . Jadi dari ketiga table di atas di tinjai dari 3 titik di lokasi kecepatan rerata tertinggi adalah pada titik 1.

Dengan menggunakan rumus matematis dari tubin kabold yang telah di uji di perairan Indonesia, maka didapatkan konversi energi arus ke daya listrik sebagai berikut:

Tabel 3. Hubungan Kecepatan Arus Laut Titik 1,2 dan 3 (m/s) dengan Daya Listrik (kW)

\begin{tabular}{|c|c|c|c|c|c|}
\hline \multicolumn{2}{|c|}{$\begin{array}{l}\text { Konversi Arus Surut Titik } 1 \text { ke } \\
\text { Daya Listrik }\end{array}$} & \multicolumn{2}{|c|}{$\begin{array}{l}\text { Konversi Arus Surut Titik } 2 \\
\text { ke Daya Listrik }\end{array}$} & \multicolumn{2}{|c|}{$\begin{array}{l}\text { Konversi Arus Surut Titik } 3 \text { ke } \\
\text { Daya Listrik }\end{array}$} \\
\hline $\begin{array}{l}\text { Kecepatan } \\
\text { Arus Laut } \\
(\mathrm{m} / \mathrm{s})\end{array}$ & $\begin{array}{l}\text { Daya Listrik } \\
\text { Turbin } \\
(\mathrm{kW})\end{array}$ & $\begin{array}{l}\text { Kecepatan } \\
\text { Arus Laut } \\
(\mathrm{m} / \mathrm{s})\end{array}$ & $\begin{array}{l}\text { Daya Listrik } \\
\text { Turbin }(\mathrm{kW})\end{array}$ & $\begin{array}{l}\text { Kecepatan } \\
\text { Arus Laut } \\
(\mathrm{m} / \mathrm{s})\end{array}$ & $\begin{array}{l}\text { Daya Listrik Turbin } \\
(\mathrm{kW})\end{array}$ \\
\hline 0,62 & 2,469814152 & 0,27 & 0,212874416 & 0,170 & 0,050329211 \\
\hline 0,67 & 3,074126009 & 0,23 & 0,119406428 & 0,170 & 0,050329211 \\
\hline 0,69 & 3,387984539 & 0,25 & 0,16015625 & 0,190 & 0,070337211 \\
\hline 0,64 & 2,660887732 & 0,23 & 0,131210761 & 0,201 & 0,083714251 \\
\hline 0,54 & 1,5915494 & 0,27 & 0,195510371 & 0,224 & 0,115554796 \\
\hline 0,42 & 0,74146412 & 0,27 & 0,198943675 & 0,201 & 0,082855648 \\
\hline 0,67 & 3,042733261 & 0,02 & $4,74537 \mathrm{E}-05$ & 0,237 & 0,136237658 \\
\hline 0,57 & 1,903976272 & 0,25 & 0,169861088 & 0,017 & $4,745370 \mathrm{E}-05$ \\
\hline 0,65 & 2,839927548 & 0,28 & 0,236779659 & 0,190 & 0,070337211 \\
\hline 0,58 & 2,044550955 & 0,36 & 0,469701019 & 0,213 & 0,099663443 \\
\hline 0,60 & 2,255126284 & 0,28 & 0,233140046 & 0,203 & 0,086307695 \\
\hline 0,02 & $4,74537 \mathrm{E}-05$ & 0,29 & 0,254010842 & 0,203 & 0,086307695 \\
\hline 0,58 & 2,022133669 & 0,29 & 0,254010842 & Maksimum (kW) & 0,136237658 \\
\hline 0,62 & 2,424772649 & 0,22 & 0,114598484 & Minimum $(\mathrm{kW})$ & 4,74537E-05 \\
\hline 0,55 & 1,667898804 & Maksimum (kW) & 0,16015625 & Rerata $(\mathrm{kW})$ & 0,077668457 \\
\hline Maksimum (kW) & 3,387984539 & Minimum (kW) & 0,254010842 & & \\
\hline Minimum (kW) & $4,74537 \mathrm{E}-05$ & Rerata $(\mathrm{kW})$ & 0,183350089 & & \\
\hline Rerata (kW) & 2,141799523 & & & & \\
\hline
\end{tabular}

Pada Tabel 4 mengenai konversi surut titik 1 ke daya listrik dapat diketaui hasil rerata listrik yang dihasikan adalah $2.14 \mathrm{~kW}$, Tabel 5 untuk titik 2 menghasilan $0.18 \mathrm{~kW}$ dan yang terkahir pada table 6 untuk titik 3 di dapatkan $0.07 \mathrm{~kW}$ potensi daya listrik yang dapatkan.

\subsection{Analisis Beban}

Kondisi daerah sebagai layanan PLTAL tersebut meliputi rumah-rumah penduduk di sekitar potensi yaitu Awerange yang terbagi dalam dua kelompok rumah penduduk, jarak total layanan (jaringan listrik) sampai konsumen total \pm 1.200 meter. Dari hasil pendataan calon pelanggan yang sudah dilakukan terdapat 64 rumah dari 3 fasilitas umum (Pelabuhan, Masjid, dan Posyandu) sehingga total pelanggan ada 67 pelanggan. Setelah mengetahui jenis dan jumlah beban, kita akan menghitung besarnya daya maksimum yang dikonsumsi oleh beban yang akan ditulis dalam satuan W (Watt) atau kW (Kilo Watt). Di bawah ini adalah kurva Load profile tiap-tiap jenis beban dan keseluruhan beban:

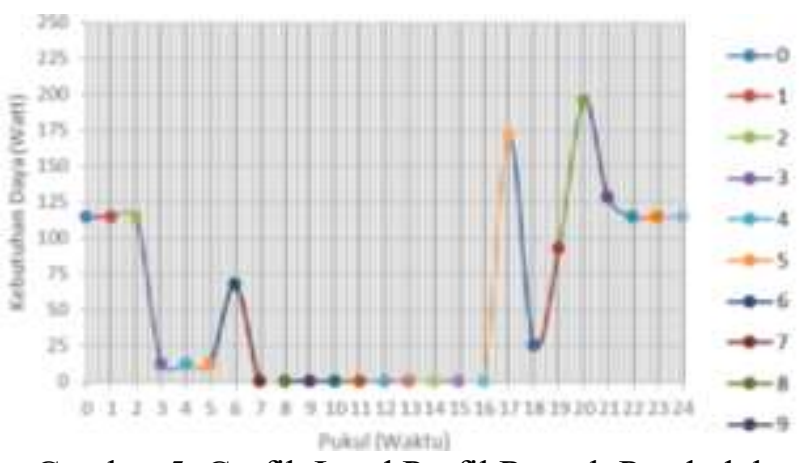

Gambar 5. Grafik Load Profil Rumah Penduduk copyright is published under Lisensi Creative Commons Atribusi 4.0 Internasional. 
Setelah mengetahui load profile harian dari jenis beban, kita dapat menghitung perkiraan besarnya daya maksimum dan total energi yang dikonsumsi oleh seluruh pelanggan yang ada di Pelabuhan Awerange dalam jangka waktu satu hari (24 jam) yang akan ditulis dalam satuan kW (Kilo Watt) untuk daya dan Wh (Watt Hour) atau KWh (Kilo Watt Hour) untuk energi. Hal ini diperlukan untuk mengetahui besarnya daya total yang dibutuhkan oleh daerah tersebut.

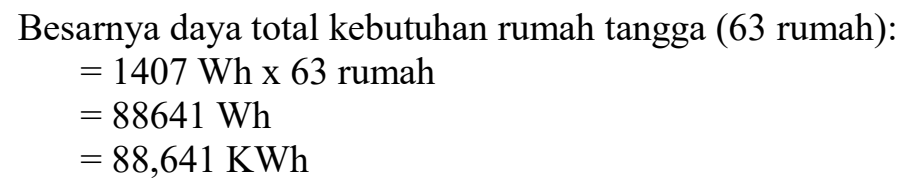

Dari kurva load profile beban terlihat bahwa konsumsi daya terbesar di Daerah Pelabuhan Awerange terjadi pada malam hari, sekitar pukul $16.00-21.00$, yaitu sebesar $25 \mathrm{~kW}-30,5 \mathrm{~kW}$. Pagi dan siang hari konsumsi daya cenderung kecil, diakibatkan oleh para penduduk yang sebagian besar bermata pencaharian sebagai nelayan dan petani, sedang berada di luar rumah di sawah kebun atau laut) sehingga tidak terjadi konsumsi daya listrik yang berarti.

\section{KESIMPULAN}

Berdasarkan hasil analisis dan hitungan yang telah dilakukan maka:

1. Energi arus laut pada teluk awerange menggunakan turbin kabold dapat menghasilkan sekitar 2,15 kW dalam kondisi arus surut. Ini sudah dapat digunakan untuk mengaliri listrik pada fasilitas umum seperti Pelabuhan, Puskesmas dll.

2. Kebutuhan konsumsi daya listrik rumah tangga dapat digunakan apabila power plant lebih dari satu buah.

3. Energi arus laut dengan turbin kabold di anggap kurang efektif karena energi yang dihasilkan tidak sebanding dengan biaya alat pembangkit listrik (turbin) sehingga tidak efesien untuk digunakan pada kasus ini.

\section{DAFTAR PUSTAKA}

[1] Adrianto, M.(2009). Studi Teknis Pemilihan Turbin Kobold pada Pembangkit Listrik Tenaga Arus Bawah Laut di Selat Madura. (Skripsi), FTK, ITS, Surabaya.

[2] Dinochen, J., (2014). Ocean currents in Indonesia. Diakses 9 Desember 2018

[3] Gil, S., (2009). (Environnement) Technologie Italienne Ponte di Archimede KOBOLD. Diakses 18 Desember 2018 dari https://gil-sun.skyrock.com/2723105456-environnement-technologie-italienneponte-di-archimede-KOBOLD.html

[4] Nugraha, A. S., Rijanto, E., (2010). Ocean Current Energy Conversion System in Wallacea Region Using Variable Speed Control Approach. Journal of Mechatronics, Electrical Power, and Vehicular Technology, $1(1), 27-34$.

[5] Rachmat, B., Usman, E., dan Kusnida, D. (2012). Potensi Arus Laut dan Konversi Daya Listrik Sebagai Energi Baru Terbarukan di Perairan Palalawan dan Indragiri Hilir, Provinsi Riau. Jurnal Geologi Kelautan, 10(2), 69-80.

[6] Togan, P., (2012). Perencanaan Sistem Penyimpanan Energi dengan Menggunakan Battery pada Pembangkit Listrik Tenaga Arus Laut (PLTAL) di Desa Ketapang, Kabupaten Lombok Timur, NTB. (Skripsi), Fakultas Teknologi Industri, ITS.Surabaya. 